\title{
Designing a Self-Assessment Item Repository: An Authentic Project in Higher Education
}

\author{
Dorothy Langley and Miky Ronen \\ Department of Instructional Systems' Technologies, \\ Holon Institute of Technology, Holon, Israel
}

\section{Langley@hit.ac.il; ronen@hit.ac.il}

\begin{abstract}
One of the challenges facing contemporary higher education is the need to design and support authentic projects reflecting knowledge and skills relevant to the students both in the academic context and future employment field. This paper presents a project for 2 nd year students preparing for careers in Instructional Technologies and Organizational Training. The project product was an interactive self-assessment item repository (SAIR) accessible via the department Learning Management System. The project involved a 3-stage instructional design, linking two courses. In the final stage student teams consulted with lecturers to ensure the quality and relevance of the product. The project design fulfils criteria for authenticity suggested by two different models.

Our 3-year study showed that the SAIR gained quantity and quality along the instructional path. Lecturers' views indicated partial satisfaction with the SAIR and the interaction with student teams, along with an acknowledgment of the essential value of the process. Students' views on tests and test items were probed prior to and following instruction, and some significant changes were found regarding tests, the usefulness of choice response test items, and their own ability to identify and correct faulty item formulation. Interviews suggested that students felt empowered by the instructional and technical tools they had gained.
\end{abstract}

Keywords: authentic project, choice response assessment item, instructional design, cognitive level, interactive learning environment, self assessment item repository

\section{Introduction}

One of the challenges facing contemporary higher education is the need to design and support authentic projects, relevant to the students in their current and expected contexts - as students and as novice professionals (Birenbaum \& Dochy, 1996; Newmann \& Archbald, 1992). These characteristics have also been related to project-based learning (e.g. Donnelly \& Fitzmaurice, 2005;

Material published as part of this publication, either on-line or in print, is copyrighted by the Informing Science Institute. Permission to make digital or paper copy of part or all of these works for personal or classroom use is granted without fee provided that the copies are not made or distributed for profit or commercial advantage AND that copies 1) bear this notice in full and 2) give the full citation on the first page. It is permissible to abstract these works so long as credit is given. To copy in all other cases or to republish or to post on a server or to redistribute to lists requires specific permission and payment of a fee. Contact Publisher@InformingScience.org to request redistribution permission.
Lasonen \& Vestrinen 2000; McGarth

2003; Morgan 1983). De Corte (2003) defines four main features of learning environments that intend to foster the productive use of knowledge and skills: "... initiate active and constructive learning processes in students, enhance students' cognitive and volitional self regulation, provide socio-cultural supports for learning through interaction \& collaboration and finally, confronting 
students as much as possible with challenging, realistic, problems and situations that have personal meaning for them and are representative for the kind of tasks they will encounter in the future."

However, creating authentic, competency-based projects, especially in the first years of higher education, presents a considerable challenge for course leaders, due to the students' novice state of knowledge and skills and the remoteness of the professional work-place context (true even for vocation-directed studies). One way we have addressed this challenge in the department of Instructional Systems Technologies is to design projects with products that are genuinely useful within the students' current organization - namely the academic context. Our students who are preparing for careers in Instructional Technologies and Organizational Training must acquire professional knowledge and skills enabling them to design questions for revision and assessment. In addition, contemporary education and training are increasingly taking place in technologicallyenhanced environments that afford vastly greater interactivity and multi-tasking than previously afforded by print-based media. Thus, the project product must function effectively within such a platform.

In this paper we shall describe a project of creating an interactive Self-Assessment Items' Repository (SAIR) for first year courses, and show that it satisfies the authenticity models offered by Newmann and Archbald (1992) and Gulikers, Bastiaens, and Kirschner, (2008), while fostering a community of learners.

\section{Instructional Design of the SAIR Project}

Although students frequently encounter assessment items on homework and examinations, they are rarely aware of the design and construction principles that have been employed to enable the items to serve specific purposes. Designing a self-assessment items' repository (SAIR) for first year courses covers a wide range of aspects, including target content and skills, levels of instructional objectives, response modes, presentation forms, interactivity, and feedback. In general, there are two assessment item formats: "constructed response" and "choice response". In the "constructed response" (also known as "open ended") format the student is required to generate an answer to a given question. In the "choice response" (CR) format the student is required to select one or more of a short list of answer options. Multiple choice (MC) items form a common example of the CR format (Birenbaum, Tatsuoka, \& Gutvirtz, 1992). The SAIR was intended to contain a variety of CR format items.

For students to succeed in the project it was necessary for course leaders to design a learning environment that would foster the productive use of acquired knowledge and skills (De Corte 2003). We have addressed this problem by implementing a 3-stage instructional sequence for our $2^{\text {nd }}$ year students, based on the integration of skills and knowledge from two concurrent courses: "Measurement and Evaluation of Learning Achievement" (MEA) and "Interactive Learning Environments" (ILE). Following are the main stages of the instructional design:

Stage 1 begins in the MEA course, where students learn about assessment item formats and principles of constructing a variety of $\mathrm{CR}$ format items. $12 \mathrm{CR}$ assessment items related to various year 1 courses are first formulated, then revised (following peer and instructor reviews) and upgraded to higher cognitive levels creating print-based collections of CR assessment items. Each team-pair submits 12 items, related to several courses and representing a variety of cognitive levels from simple recall to application according to Bloom's taxonomy (Bloom \& Krathwohl, 1956).

Stage 2: Parallel to the stage 1 activity, the ILE course deals with principles of Interactivity and the main features of the computer-based platform in which the SAIR will be embedded. In stage 
2 , the sequence continues in the ILE course where the items are reformulated in the interactive computer-based environment, adding a variety of response and feedback options.

Stage 3 was launched towards the end of the ILE course and involved matching student teams with course lecturers, according to team preferences and strengths. As an initial resource, the teams received the accumulated output of stage 2 for the given course. The teams and lecturers collaborated, through cycles of feedback and revision, to create a comprehensive self assessment item repository for the course.

An alternative stage 3 option was implemented in the Web-based Teaching (WBT) course during the following semester. Student teams designed, constructed, and implemented web-based minicourses which included CR assessment items.

\section{Study Design and Tools}

\section{Instructional Sequence and Research Structure}

The study spanned a period of three academic years (cycles 1,2,3) with some variations, as shown in Table 1. We employed several research tools: pre- and post-questionnaires of student views, interviews with students, and a questionnaire for lecturers participating in stage 3 . In addition, we analyzed the SAIR, focusing on four courses representing different instructional domains.

Table1: Instructional sequence and research structure

\begin{tabular}{|c|c|c|c|c|}
\hline \multicolumn{2}{|c|}{\begin{tabular}{|l} 
Study Design \\
\end{tabular}} & Cyclel & Cycle2 & Cycle3 \\
\hline \multicolumn{2}{|l|}{ Pretest } & - & + & + \\
\hline Stage 1 & $\begin{array}{l}\text { MEA course: ite ms are first formulated, } \\
\text { then revised and upgraded to higher } \\
\text { cognitive levels creating a print-based } \\
\text { collection }\end{array}$ & + & + & + \\
\hline Stage 2 & $\begin{array}{l}\text { ILE course: items are reformulated for } \\
\text { application in a web based environment } \\
\text { \& peer evaluation of items }\end{array}$ & + & + & + \\
\hline \multirow{2}{*}{ Stage 3} & $\begin{array}{l}\text { Project MEA \& ILE co urses: } \\
\text { Teams guided by lecturers create a web- } \\
\text { based question repository for courses }\end{array}$ & & + & \\
\hline & $\begin{array}{l}\text { WBT course (following semester): } \\
\text { Formulating and implementing a web } \\
\text { based test for a mini-course }\end{array}$ & & & + \\
\hline \multicolumn{2}{|c|}{ Lecturers' questionnaire \& interviews } & & + & \\
\hline \multicolumn{2}{|l|}{ Posttest } & + & + & + \\
\hline \multicolumn{2}{|c|}{ Interviews - students } & + & + & + \\
\hline
\end{tabular}

Cycle 1 lacked a pretest because it was the first time the courses were taught. Only during cycle 1 did we realize how the courses were interacting with the students' naive attitudes and beliefs. Cycles 2 and 3 represent alternative types of the full project-based process: Cycle 2 culminated in collaboration with content and pedagogy experts (lecturers); Cycle 3 culminated in an authentic collaborative implementation project of preparing assessment items for student designed webbased courses. The switch between implementation models was driven by the need to avoid re- 
peated demands on the lecturers, as well as the need to satisfy the requirements of the web-basedteaching course.

\section{Research Questions}

1. How did the Self Assessment Items' Repository (SAIR) for sample courses evolve during the instructional sequence?

2. What was the lecturers' evaluation of the final SAIR for their course and of their collaboration with the student teams?

3. How did the instructional sequence affect student views regarding Choice Response (CR) assessment items?

4. To what extent was the project compatible with models of authentic projects?

\section{Findings \& Discussion}

\section{Study 1- Characteristics of the SAIR}

In stage 1 student pairs formulated 12 print-based items for first year courses. The stage 1 repository totaled about 300 self-assessment items containing text and graphics, clearly inspired by the students' previous year's learning experiences. The questions were varied CR items (multiple choice, matching, true-false, and completion). The formulation, clarity, cognitive level, and presentation improved following peer and instructor feedback.

Item type distribution: The breakdown of item-types was similar in all 3 cycles. Multiple Choice items with 4-5 distractors were used most frequently, followed by "Matching" items. The True-False type items formed a significant minority, usually involving a batch of related statements. About $20 \%$ of the items were Completion type items (simple sentence, cloze, or concept map).

Content areas and Cognitive levels: The questions covered a variety of courses and consisted of text and visuals. Some items appeared more frequently due to the common learning experience. Initially the students constructed assessment items at the recall level. During stage 1 they were required to upgrade the cognitive level of at least half the items to comprehension or application levels. Following is an example of an item for the course "Legislation, the Internet and Intellectual Property":

Basic version (knowledge recall level)

Copyright can be claimed for

(Check the incorrect option)

a. an idea

b. a process and method

c. a mathematical concept

d. a fact or data item

e. a way of expression

Upgraded version (Application level)

John and Mary were members in a product development team in a leading company. During one of the team meetings, John suggested an improvement in the production process of the product, and his suggestion was rejected by the team. Some months later, Mary left the company to join a competitor, and within a short while implemented John's suggestion. Mary could be charged with breach of copyright because she appropriated... 
(check all that apply)
a. an idea
b. a process and method
c. a mathematical concept
d. a fact or data item
e. a way of expression

In Stage 2 the items were embedded in an interactive web-based environment. Correct answers and feedback options were formulated and implemented using the environment's interactive mechanism (Figure 1). The quality of the embedded graphics also showed some improvement.

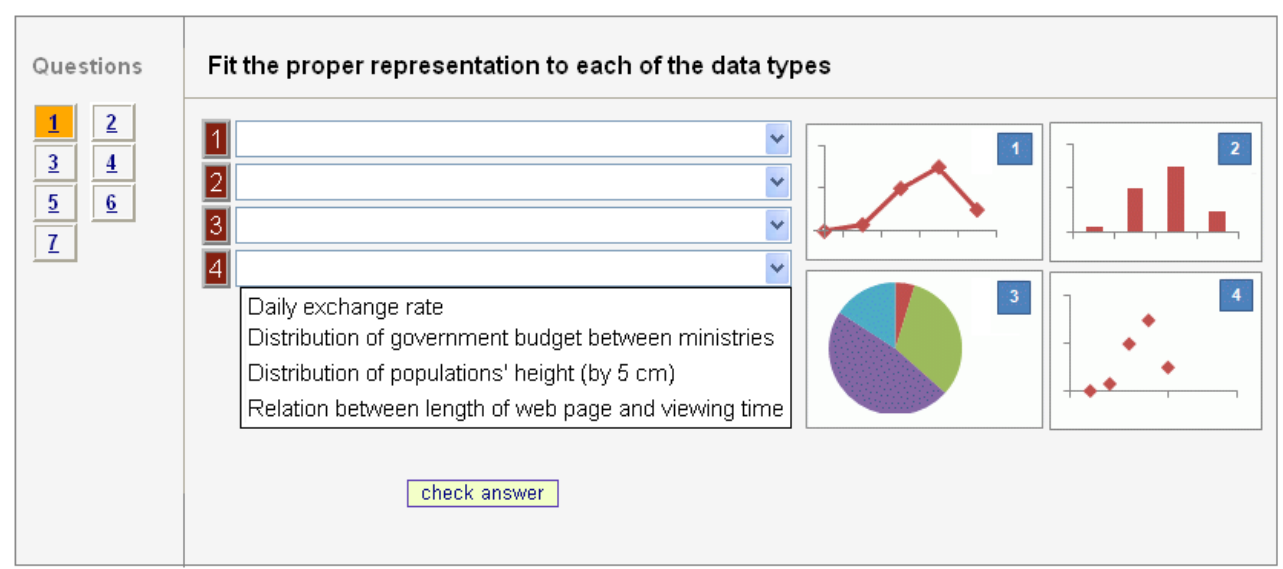

Figure 1: An example of a "matching" type item from the web based repository created for the Knowledge Organization and Representation course.

Stage 3 brought about team specialization in particular courses, involving an interaction with course lecturers. There is evidence of a greater sophistication of questions, more case-based problem solving, and more instances of accessing external files as data resources. The total number of questions more than doubled, and courses that had not been covered acquired a sizeable repository. It is important to note that due to the common learning experience, similar questions for a given course appeared in all three cycles.

\section{Analysis of the SAIR for Sample Courses}

We have decided to compare the stage 3 products to the initial resources students were given, i.e. their own, and the previous year's stage 2 web-based repositories. The final repository contains several hundreds of questions in 15 courses, from which we have selected a sample of 4 courses, representing different disciplines. We shall analyze the following aspects per course: number of questions, organization of questions into topics, question types, cognitive levels, and representation modes.

We have characterized the repository items using three categories: question type, cognitive level, and representation format (Table 2a). 
Table 2a: Repository items classification

\begin{tabular}{|l|l|l|}
\hline Question type & Cognitive level & Representation format \\
\hline a - Array match & K - Knowledge & t - Text only \\
b - Mark & C - Comprehension & v-Visual \& multimedia \\
c - Order / match & A - Application & \\
d - Multiple choice verbal & & \\
e - Multiple choice visual & & \\
f - Text insert & & \\
\hline
\end{tabular}

Table $2 \mathrm{~b}$ shows the data for the selected courses. Following is the breakdown of items in the repositories of the 4 selected courses. It is important to note that the classification of topics and cognitive levels is not absolute. Naturally, some questions dealt with several topics. Likewise, it was sometimes difficult to make the distinction between the cognitive levels of "recall" and "comprehension".

Table 2b: Repository item data for sample courses

\begin{tabular}{|c|c|c|c|c|c|c|c|c|c|c|c|c|c|}
\hline \multirow{2}{*}{ Cycle } & \multirow{2}{*}{$\begin{array}{c}\text { \# of } \\
q\end{array}$} & \multirow{2}{*}{$\begin{array}{l}\text { \# of } \\
\text { topics }\end{array}$} & \multicolumn{6}{|c|}{$\begin{array}{c}\text { types } \\
(\%)\end{array}$} & \multicolumn{3}{|c|}{$\begin{array}{l}\text { Cognitive } \\
\text { level (\%) }\end{array}$} & \multicolumn{2}{|c|}{$\begin{array}{c}\text { Representation } \\
(\%)\end{array}$} \\
\hline & & & $\mathbf{a}$ & $\mathbf{b}$ & $\mathbf{c}$ & $\mathbf{d}$ & $\mathbf{e}$ & $\mathbf{f}$ & $\mathbf{K}$ & $\mathbf{C}$ & A & $\mathbf{t}$ & v \\
\hline \multicolumn{14}{|c|}{ For course: Introduction to psychology and learning theories } \\
\hline Cycle 1 & 45 & 2 & 7 & 33 & 20 & 29 & 4 & 7 & 53 & 47 & 0 & 49 & 51 \\
\hline Cycle2 & 24 & 6 & 3 & 12 & 2 & 4 & 0 & 3 & 33 & 67 & 0 & 70 & 30 \\
\hline Cycle2 stage 3 & 39 & 5 & 2 & 0 & 5 & 82 & 5 & 2 & 5 & 95 & 0 & 95 & 5 \\
\hline \multicolumn{14}{|c|}{ For course: Introduction to computer programming } \\
\hline Cycle 1 & 15 & 5 & 7 & 0 & 28 & 44 & 7 & 14 & 27 & 20 & 53 & 80 & 20 \\
\hline Cycle2 & 3 & 3 & 33 & 67 & 0 & 0 & 0 & 0 & 33 & 0 & 67 & 67 & 33 \\
\hline Cycle2 stage 3 & 49 & 7 & 4 & 2 & 11 & 65 & 0 & 18 & 31 & 28 & 41 & 98 & 2 \\
\hline \multicolumn{14}{|c|}{ For course: Introduction to Social Science Research Methods } \\
\hline Cycle 1 & 21 & 9 & 5 & 5 & 5 & 70 & 5 & 10 & 19 & 62 & 19 & 71 & 29 \\
\hline Cycle2 & 15 & 8 & 14 & 14 & 7 & 58 & 0 & 7 & 27 & 60 & 13 & 27 & 73 \\
\hline Cycle2 stage 3 & 58 & 13 & 22 & 2 & 4 & 68 & 2 & 2 & 2 & 76 & 22 & 69 & 31 \\
\hline \multicolumn{14}{|c|}{ For course: Knowledge Organization and Representation } \\
\hline Cycle 1 & 2 & 1 & 0 & 0 & 50 & 50 & 0 & 0 & 0 & 100 & 0 & 0 & 100 \\
\hline Cycle2 & 4 & 3 & 0 & 25 & 25 & 50 & 0 & 0 & 50 & 50 & 0 & 25 & 75 \\
\hline Cycle 2 stage 3 & 26 & 6 & 15 & 15 & 31 & 19 & 15 & 0 & 11 & 85 & 4 & 20 & 80 \\
\hline
\end{tabular}

Scanning the data in Table $2 \mathrm{~b}$ we have noticed several trends: an increase in the total number of items and topics, a greater variety of items, and a shift towards higher cognitive levels. It would seem that the specialization process and the critical feedback by involved lecturers promoted the construction of a SAIR of higher quality. However, it is important to remember that lecturer feedback was not always fully implemented by the teams who were ultimately responsible for the 
end product. An important aspect which awaits future analysis is the linguistic formulation of the questions in the final stage relative to the previous ones.

\section{Study 2 - Lecturers' Evaluations}

Ten lecturers, who participated in constructing the stage 3 final repository, responded to a reflective questionnaire about the process and product of their collaboration with the student teams.

Table 3 summarizes lecturers' responses regarding the SAIR status and future intentions. In spite of a certain approval of topic coverage, question organization, cognitive level, and correctness of answers, the general assessment of the current repositories was medium-low in all aspects.

Table 3: Summary of lecturers' responses

\begin{tabular}{|c|c|c|c|c|c|}
\hline Repository Status & \multicolumn{5}{|c|}{ Lecturers' response (\%) $\mathrm{N}=10$} \\
\hline Topics coverage & $\begin{array}{c}\text { Ful1 } \\
10\end{array}$ & \multicolumn{2}{|l|}{$\begin{array}{c}\text { Partial } \\
80\end{array}$} & \multicolumn{2}{|r|}{$\begin{array}{c}\text { Poor } \\
10\end{array}$} \\
\hline Question organization & $\begin{array}{c}\text { Appropriate } \\
20\end{array}$ & \multicolumn{2}{|c|}{$\begin{array}{l}\text { Requires improve ment } \\
60\end{array}$} & \multicolumn{2}{|c|}{$\begin{array}{c}\text { Requires major review } \\
20\end{array}$} \\
\hline Item formulation & $\begin{array}{c}\text { Appropriate } \\
40\end{array}$ & \multicolumn{2}{|l|}{$\begin{array}{c}\text { Reasonable } \\
30\end{array}$} & \multicolumn{2}{|c|}{$\begin{array}{c}\text { Requires major review } \\
30\end{array}$} \\
\hline Cognitive level & $\begin{array}{c}\text { High } \\
0\end{array}$ & \multicolumn{2}{|l|}{$\begin{array}{l}\text { Medium } \\
70\end{array}$} & \multicolumn{2}{|r|}{$\begin{array}{c}\text { Low } \\
30\end{array}$} \\
\hline Correct answer indic ation & $\begin{array}{l}\text { Correct } \\
30\end{array}$ & \multicolumn{2}{|c|}{$\begin{array}{c}\text { Mostly correct } \\
70\end{array}$} & \multicolumn{2}{|c|}{$\begin{array}{c}\text { Mostly wrong } \\
0\end{array}$} \\
\hline Feedback & $\begin{array}{c}\text { Satisfactory } \\
10\end{array}$ & \multicolumn{2}{|c|}{$\begin{array}{c}\text { Quite satisfactory } \\
50\end{array}$} & \multicolumn{2}{|c|}{$\begin{array}{c}\text { Unsatisfactory } \\
40\end{array}$} \\
\hline Open ite ms & $\begin{array}{c}\text { Too many } \\
0\end{array}$ & \multicolumn{2}{|c|}{$\begin{array}{c}\text { appropriate } \\
60\end{array}$} & \multicolumn{2}{|c|}{$\begin{array}{c}\text { Too few } \\
40\end{array}$} \\
\hline CR items & $\begin{array}{c}\text { Good variety } \\
30\end{array}$ & \multicolumn{2}{|l|}{$\begin{array}{l}\text { Quite varied } \\
40\end{array}$} & \multicolumn{2}{|c|}{$\begin{array}{c}\text { Missing types } \\
20\end{array}$} \\
\hline Links to files or sites & $\begin{array}{c}\text { Too many } \\
0\end{array}$ & \multicolumn{2}{|l|}{$\begin{array}{c}\text { Appropriate } \\
10\end{array}$} & & $\begin{array}{l}\text { Ooo few } \\
90\end{array}$ \\
\hline Interactive multimedia & $\begin{array}{c}\text { Too much } \\
0 \\
\end{array}$ & \multicolumn{2}{|l|}{$\begin{array}{c}\text { Appropriate } \\
20 \\
\end{array}$} & \multicolumn{2}{|c|}{$\begin{array}{c}\text { Too little } \\
80\end{array}$} \\
\hline \multicolumn{6}{|l|}{ Intended future use } \\
\hline \multicolumn{2}{|c|}{$\begin{array}{l}\text { To what extent is the SAIR in your course ready to } \\
\text { serve year } 1 \text { students in the coming academic year? }\end{array}$} & $\begin{array}{c}\text { Fully ready } \\
10 \\
\end{array}$ & \multicolumn{2}{|c|}{$\begin{array}{l}\text { Quite ready } \\
50\end{array}$} & $\begin{array}{c}\text { Not ready } \\
40\end{array}$ \\
\hline \multicolumn{2}{|c|}{$\begin{array}{l}\text { Do you intend to direct students to use the current } \\
\text { question repository? }\end{array}$} & $\begin{array}{c}\text { Probably yes } \\
70\end{array}$ & \multicolumn{2}{|c|}{$\begin{array}{l}\text { Don't know } \\
20\end{array}$} & $\begin{array}{c}\text { Probably not } \\
10\end{array}$ \\
\hline \multicolumn{2}{|c|}{$\begin{array}{l}\text { Would you be interested in mentoring next year's } \\
\text { students towards completing the SAIR in your } \\
\text { course? }\end{array}$} & $\begin{array}{l}\text { Probably yes } \\
60\end{array}$ & \multicolumn{2}{|c|}{$\begin{array}{l}\text { Don't know } \\
30\end{array}$} & $\begin{array}{c}\text { Probably not } \\
10\end{array}$ \\
\hline
\end{tabular}

The lecturers considered the repositories in their courses partially ready or even unready for use. Yet, a tendency to expose following freshmen to the repositories was discernable. There was a moderate willingness to continue the mentoring process to achieve a better repository.

Lectures' feelings on aspects regarding the mentoring process of student teams were expressed on a four level scale, with the extreme options explicated and two intermediate options provided.

Figure 2 shows the average level of feelings for each aspect of the mentoring process. 


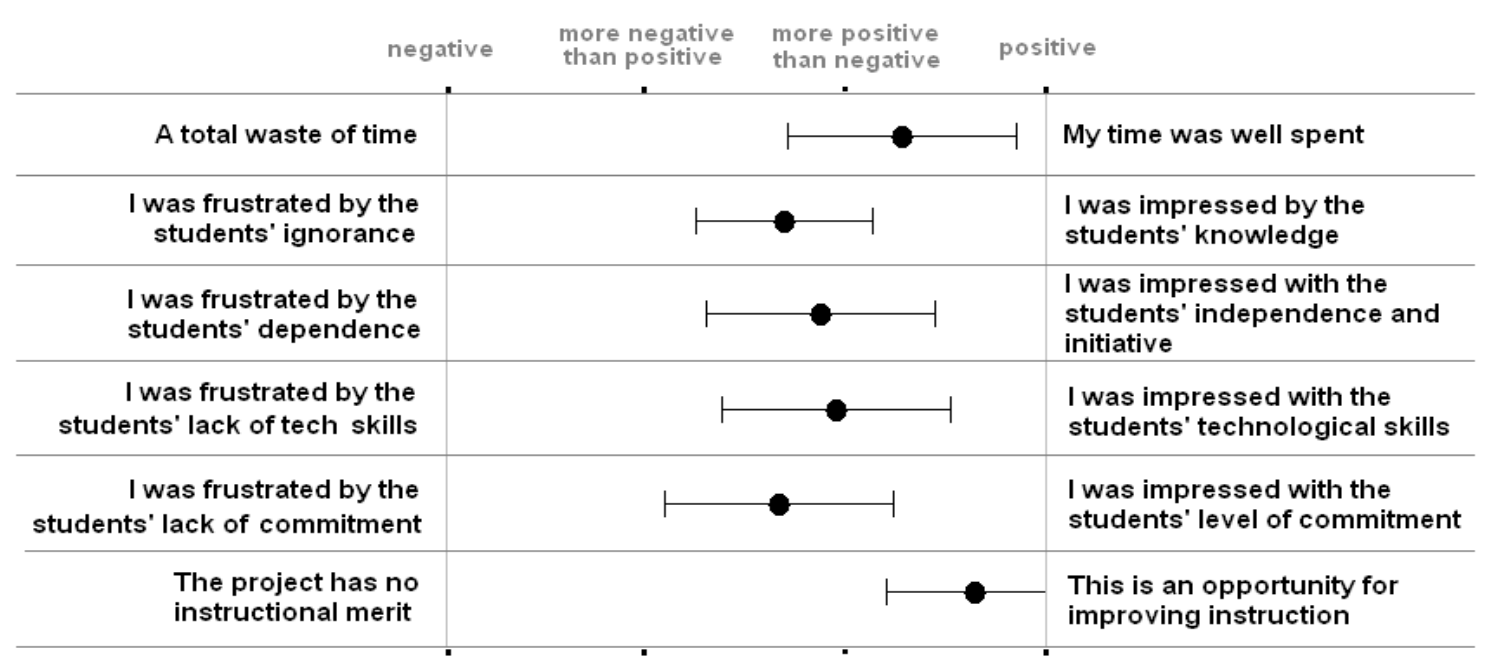

Figure 2: Lectures' feelings about the mentoring process

Lecturers' feelings concerning the levels of knowledge and commitment of student teams were moderate-low, and somewhat more positive regarding independence and technological skills. A "strong negative" attitude was only expressed by a single lecturer with respect to "student commitment". It is important to understand that with a small sample $(\mathrm{N}=10)$ the average is strongly affected by extreme values. Obviously, the mentoring activity was experienced differently by different lecturers. Creating assessment items of high quality is a demanding task for second year students. The student teams were varied in terms of knowledge and commitment, thus their ability to respond effectively to lecturer comments varied. The amount of guidance and feedback teams received depended on the lecturers' willingness to devote time to the project. A dedicated lecturer, with high expectations, working with a mediocre, unresponsive student team would naturally feel frustrated. In spite of the overall tone of disappointment, lecturers tended to feel that their time investment was quite worthwhile and that the project provided an opportunity to improve instruction.

\section{Study 3 - Students' Views on Assessment Items}

Higher education students' views regarding tests and test items are forged by their experiences in previous educational frameworks. The assessment literature indicates that student views regarding assessment formats are related to personality traits and perceptions of fairness and utility (Birenbaum, 1997, 2007; Birenbaum \& Feldman, 1998; Struyven, Dochy, \& Janssens, 2005). We were interested to discover whether placing students "in the driver seat" by providing them with knowledge and experience for designing Choice Response (CR) assessment items would affect their views regarding tests in general, and CR items in particular.

A questionnaire containing 11 statements probing student views about tests, attitudes towards CR items, and particular skills related to CR items was administered prior to and following the instructional sequence. The students marked their views on a five level scale ( $1=$ strongly disagree, disagree, no opinion, agree, $5=$ strongly agree). The questionnaire was administered via the web using the CeLS environment (Ronen, Kohen-Vacs, \& Raz-Fogel, 2006).

In the following we shall describe the particular circumstances of each implementation cycle and provide representative quantitative and qualitative results.

Cycle 1 can be considered a pilot implementation, with a relatively small sample $(\mathrm{N}=18)$. The questionnaire was administered only at the end of stage 2 and consisted of 10 of the 11 items. We 
also asked students to indicate for each item whether their views had changed since the beginning of the semester.

Cycle 2 included all the components of the instructional design with a sizeable sample $(\mathrm{N}=29)$. The pre-test was administered at the beginning of stage 1 and the post-test after stage 2 .

Cycle 3 included all the components of the instructional design with an even larger sample $(\mathrm{N}=44)$. However, stage 3 was implemented in the Web based Training (WBT) course in the second semester and the post-test was administered at its end.

Table 4 shows, for cycle 1, the percentage of students who stated that their views had changed. For cycles $2 \& 3$ the table shows the average response per questionnaire item and the results of paired, one tailed t-tests performed on the samples. Only the responses of students who participated on both occasions were considered.

Table 4: Students' responses to views questionnaire

\begin{tabular}{|c|c|c|c|c|c|c|c|c|}
\hline \multirow{2}{*}{\multicolumn{2}{|c|}{ Questionnaire Item }} & \multirow{3}{*}{$\begin{array}{c}\begin{array}{c}\text { Cycle1 } \\
(\mathbf{N}=18)\end{array} \\
\begin{array}{c}\text { Change } \\
(\%)\end{array} \\
11\end{array}$} & \multicolumn{3}{|c|}{$\begin{array}{l}\text { Cycle2 } \\
(\mathbf{N}=29)\end{array}$} & \multicolumn{3}{|c|}{$\begin{array}{l}\text { Cycle3 } \\
(\mathrm{N}=44)\end{array}$} \\
\hline & & & pre & nost & $\mathbf{n}$ & nre & nost & \\
\hline 1 & Tests promote feelings of anxiety. & & 3.76 & 3.41 & .043 & 3.73 & 3.57 & .15 \\
\hline 2 & Tests promote improve ment. & 33 & 3.52 & 3.93 & $.032^{*}$ & 3.16 & 3.16 & .5 \\
\hline 3 & $\begin{array}{l}\text { Tests serve mainly administrative } \\
\text { purposes. }\end{array}$ & 39 & 3.34 & 2.69 & $.018^{*}$ & 2.82 & 3.05 & 131 \\
\hline 4 & Tests drive me to study. & 17 & 3.72 & 4.17 & $.031^{*}$ & 3.34 & 3.50 & .113 \\
\hline 5 & I prefer tests with CR items. & 11 & 3.52 & 3.83 & .06 & 3.43 & 3.39 & 408 \\
\hline 6 & $\begin{array}{l}\text { It is possible to design a variety of } \\
\text { CR items. }\end{array}$ & 44 & 4.55 & 4.86 & $.04{ }^{\star}$ & 4.20 & 4.43 & $.043^{\star}$ \\
\hline 7 & $\begin{array}{l}\text { CR items evaluate mainly factual } \\
\text { knowledge. }\end{array}$ & $\begin{array}{c}\text { Not } \\
\text { included }\end{array}$ & 3.10 & 2.14 & $.003^{\star \star}$ & 3.32 & 2.75 & $.001^{\wedge *}$ \\
\hline 8 & $\begin{array}{l}\text { I can identify leaming objectives in } \\
\text { CR items on a subject I know. }\end{array}$ & 67 & 3.90 & 4.28 & $.031 *$ & 3.68 & 3.61 & .32 \\
\hline 9 & $\begin{array}{l}\text { I can identify formulation faults in } \\
\text { CR items. }\end{array}$ & 94 & 4.03 & 4.66 & $.0001^{\star x}$ & 3.82 & 4.25 & $.003^{x /}$ \\
\hline 10 & $\begin{array}{l}\text { I can take advantage of formulation } \\
\text { faults in } \mathrm{CR} \text { items. }\end{array}$ & 78 & 3.83 & 4.45 & $.002^{\wedge *}$ & 3.14 & 3.55 & .06 \\
\hline 11 & $\begin{array}{l}\text { I can suggest ways to improve } \mathrm{CR} \\
\text { items. }\end{array}$ & 94 & 3.83 & 4.59 & $.0002^{\wedge k}$ & 3.82 & 4.14 & 057 \\
\hline
\end{tabular}

Cycle 1. A considerable proportion of the students reported increased awareness of the variety of CR item types, ability to identify learning objectives, ability to identify formulation faults, ability to take advantage of formulation faults, and ability to suggest ways of improving formulation.

Cycle 2. The trends of change indicated in cycle 1 achieved statistical significance in cycle 2 . The MAE course dealt with the different functions filled by assessment, e.g., formative feedback and instructor self-appraisal. Thus, we can understand the decreased support for the common belief that "tests serve mainly administrative purposes." Students gained considerable experience in for- 
mulating a variety of $\mathrm{CR}$ items in both courses. Thus, their increased awareness of the existing variety of such items could be expected to increase. The discussion and application of Bloom's taxonomy of cognitive objectives extended the span of the kinds of knowledge CR items could be used to assess. Great emphasis was given to optimal formulation of CR items and common formulation errors. This emphasis expressed itself in the students' increased confidence in being able to detect formulation faults, to take advantage of formulation faults (to increase guessing probability), and to improve item formulation.

Cycle 3. In cycle 3 we can detect similar trends of change to those found in cycle 2 . However, the differences were significant for only three of the questionnaire items. This can be ascribed to the fact that the post test was administered a full semester after studying the relevant first semester courses.

We may conclude that the instructional sequence was effective in providing a better understanding of the assessment potential of CR items and of the formulation principles that should be employed to achieve that potential. Further evidence of students' views can be gained from the verbal comments that were added to the questionnaires.

\section{Initial views}

In the cycle 2 pretest, two main themes were discerned in the free comments students added:

\section{The function of tests and test anxiety}

- I consider tests as a springboard to learning. Personally, without a test I would find it difficult to sit down and study.

- I have discovered during the past year that, in spite of its disadvantages, my test anxiety sometimes produces higher achievement levels, because it motivates me to study and succeed.

- I believe that different test types can emphasize different learning abilities of various learners. Those with a good memory for detail will do better on closed test items.

- Good formulation of the items is critical for attaining the learning goals.

\section{Closed test are easier, but have limitations}

- A closed test can sometimes help some of the students handle the anxiety. If a student is uncertain of the answer, he can sometimes understand from the question formulation what the correct option should be.

- Grading a closed test is much easier and it yields the grade - immediately and exactly.

- I prefer closed tests because I feel it is easier to prepare for them. The questions help me remember the material.

- An open test is of higher quality, and represents knowledge better. It is a truer measure of knowledge.

- In an open test the student can better enjoy the experience, as he can bring additional knowledge beyond that given during instruction.

- Well formulated closed tests can be objective and representative. However, they do not allow the student to express himself.

- Students consider closed tests easier - but they are wrong.

- Closed tests often measure reading comprehension rather than content knowledge. 


\section{Post instruction views and comments}

Cycle 2: Which of the activities during the semester affected your conception of CR assessment items?

- Constructing the question repository through cycles of alteration and improvement.

- Defining the cognitive level of each item according to Bloom's taxonomy.

- Peer evaluation and feedback.

- Composing the items ourselves and upgrading them.

- The mid-term MAE exam questions dealing with CR test items.

- Converting the printed question repository to an interactive, web-based environment.

- Activities in both courses (MAE \& ILE)

Cycle 3: How did the assessment items activities in the first semester contribute to the WBT course?

Analysis of the students' answers reveals the following themes:

- General contribution to mini-course assessment item construction.

- Improved skills in using the LMS interactive question mechanism.

- Ability to construct CR items of various cognitive levels according to Bloom's taxonomy.

- Ability to correctly formulate and design distractors to ensure an appropriate difficulty level.

- Overall schema of what was required and how to achieve it. Skills that could be implemented effectively in the new situation.

"I knew what faced me and how to go about the task."

"I was able to think ahead of what I wanted to assess, and I formulated questions according to the principles we had learnt."

In what way did your conception of CR type items change?

Analysis of the students' answers reveals the following themes:

- CR type items have structure (stem, distractors and instructions).

- There are different types of CR items.

- $\mathrm{CR}$ items require careful formulation.

- Constructing CR items is not easy.

- CR items can be used to assess different knowledge levels, not just factual knowledge.

- Give-away distractors help guesswork and selection by elimination.

\section{Summary of study 3}

The results of study 3 show that the instructional sequence affected student views regarding tests and test items in several ways. As students gained knowledge and skills concerning assessment purposes and styles they became able to view the assessment scene from a wider perspective, and see the instructional, as well as the administrative, functions of tests. 
Learning about CR item types, levels of cognitive objectives and item formulation rules gave students the power to analyze given assessment items and to produce quality items for target courses.

The skills and perspective afforded by the Interactive Learning Environment's course provided professional tools for producing a useful contemporary product from which members of the academic community could benefit. The feeling of enhanced ability is clearly voiced in student comments to the post-questionnaires, as well as in anecdotal private communications.

\section{Study 4 - Authenticity Features of the Instructional Design}

We shall evaluate the authenticity of the described project using criteria from two sources: Newmann \& Archbald (1992) and Gulikers et al. (2008). Newmann \& Archbald (1992) define 3 indicators of authentic achievement by professionals: production of knowledge, disciplined inquiry, and value beyond evaluation. Production of knowledge is manifested in our projects by designing and producing self-assessment items of specific cognitive levels and by providing correct answers and feedback in a web-based platform. Disciplined inquiry is manifested by acquiring knowledge in the MAE and ILE courses, as well as the courses for which the self assessment items are intended, by in-depth understanding and integration of knowledge and skills. The "value beyond evaluation" criterion is satisfied by the aesthetic, utilitarian, and personal value of the SAIR beyond documenting the competence of our second year students.

The instructional design provided the required conditions for authentic projects: peer-to-peer and peer-lecturer collaboration, access to tools and resources, worker-discretion \& opportunity for ownership (e.g., stage 3 course selection), and flexible use of time within the constraints of the academic schedule.

Gulikers et al., (2008) define 5 indicators for evaluating the authenticity of projects: task, physical contexts, social contexts, assessment form, and results and criteria. In the following we shall show that these indicators are all present in our instructional design.

\section{Task}

- Organizational training involves the design of reliable and valid assessment tools covering content and skills at the required levels.

- The project clearly integrates knowledge, skills and attitudes from several courses.

- The criterion-task involves a supplier- client relationship, which is simulated in stage 3 by the interaction between student team and the course lecturer.

- The student team (supplier) is dependant on the lecturer's (client) approval.

- The task is perceived as relevant by all parties.

\section{Physical context}

- The course provides a sufficient but restricted time interval to perform the task.

- The interactive LMS environment and the email communication facilitate interactions during the process and provide a setting for the final product.

\section{Social context}

- For stage 3 student teams are given "lecturer status" in the designated LMS environment. 
- The level of collaboration resembles that of a training team preparing assessment materials with team members contributing their dominant skills.

- The project involves two levels of social relationships (peer-peer, peers-experts) which are likely to exist in real life situations.

- Organizational training involves the design of reliable and valid assessment tools covering content and skills at the required levels.

- The project clearly integrates knowledge, skills and attitudes from several courses.

- The criterion-task involves a supplier- client relationship, which is simulated in stage 3 by the interaction between student team and the course lecturer.

- The student team (supplier) is dependant on the lecturer's (client) approval.

- The task is perceived as relevant by all parties.

\section{Assessment form}

Students observably demonstrate their professional competencies by creating a quality product they can be required in real life.

\section{Results and Criteria}

- The result is a realistic and valued product in professional life.

- Criteria are set and made explicit and transparent to learners from the start.

Judging by the above mentioned criteria, we can conclude that the nature of the project and the instructional design supporting it justify its characterization as an authentic project. The project is relevant to several circles of learner communities: individual teams carrying out the assignment, the entire second year cohort, lecturers of the assigned courses, and future first year students and lecturers.

The community aspects are manifested through the idea of dividing up a large project between teams, the use of a web-based platform accessible to all project participants, the adoption of an open submission regime allowing legitimate sharing, the implementation of peer evaluation at each stage, interaction with faculty experts as project clients, and the basic objective that the product will benefit future learners.

\section{Theoretical and Practical Implications}

Higher education faces many challenges in bridging the gap between academic and workplaceoriented goals. Our experience suggests that the course ahead can be steered by taking an integrative view of the undergraduate syllabus and finding links to the future employment scene. The following conditions are required to help sustain the process:

1. Authentic, challenging, and feasible learning opportunities can be created by imaginative instructional design, sometimes looking beyond the horizon of a given course. This is particularly true in vocation-directed instructional contexts. The project can be revisited in different courses, evolving along a spiral learning path, and affording opportunities for transfer of learning to new contexts.

2. Students need to be able to feel the utility of the project in which they are involved both for themselves and for the wider community. This can be achieved by dealing with a real need and by 
awarding the participating students "status symbols" (such as lecturer status in the LMS) and direct collaboration with experts.

3. Considerable coordination and collaboration between course leaders is required to facilitate multi-disciplinary projects. Department heads need to foster and encourage an atmosphere of an instructional community to facilitate such projects.

Further research is required to find out the effect of the interaction with students in creating the SAIR on lecturers' conception and organization of their courses and the extent to which the involvement in creating an SAIR enhances the students' knowledge and skills in the chosen course.

\section{References}

Birenbaum, M. (1997). Assessment preferences and their relationship to learning strategies and orientations. Journal of Higher Education, 33, 71-84.

Birenbaum, M. (2007). Assessment and instruction preferences and their relationship with test anxiety and learning strategies. Higher Education, 53, 749-768.

Birenbaum, M., \& Dochy, F. J. R. C. (1996). Alternatives in assessment of achievements, learning processes and prior knowledge. Boston, MA: Kluwer Academic.

Birenbaum, M., \& Feldman, R. A. (1998). Relationships between learning patterns and attitudes towards two assessment formats. Educational Research, 40(1), 90 - 98.

Birenbaum, M., Tatsuoka, K. K., \& Gutvirtz, Y. (1992). Effects of response format on diagnostic assessment of scholastic achievement. Applied Psychological Measurement, 16, 353-363.

Bloom, B. S., \& Krathwohl, D. R. (1956). Taxonomy of educational objectives: The classification of educational goals, by a committee of college and university examiners. Handbook I: Cognitive domain. New York: Longman, Green.

De Corte, E. (2003). Designing learning environments that foster the productive use of acquired knowledge and skills. In E. De Corte, L. Verschaffel, N. Entwistle, \& J, van Merrienboer (Eds.), Powerful learning environments: Unravelling basic components and dimensions (pp. 21-33). Oxford, UK: Elsevier Science Ltd.

Donnelly, R., \& Fitzmaurice, M. (2005). Collaborative project-based learning and problem-based learning in higher education: A consideration of tutor and student roles in learner-focused strategies. In G., O’Neill, S., Moore, \& B., McMullin, (Eds.), Emerging issues in the practice of university learning and teaching (pp. 87-98). Dublin:AISHE. Retrieved from http://www.aishe.org/readings/2005-1/donnellyfitzmaurice-Collaborative-Project-based-Learning.pdf

Gulikers, J., Bastiaens, Th., \& Kirschner, P. (2008). Defining authentic assessment: Five dimensions of authenticity. In A. Havnes, \& L. McDowell (Eds.), Balancing dilemmas in assessment and learning in contemporary education (pp. 73-86). NY: Routledge.

Lasonen, J., \& Vesterinen, P. (2000). Work-based learning in vocational higher education programmes: A Finnish case of project-based learning. Paper presented at the Annual Conference of the Association for Career and Technical Education/International Vocational Education and Training Association (San Diego, CA, December 7-10, 2000).

McGrath, D. (2003). Artifacts and understanding: What kinds of products should we consider having our students construct as a result of project-based learning (pbl)? What factors do we need to consider as we design project tasks? Learning \& Leading with Technology, 30(5), 22-27.

Morgan, A. (1983). Theoretical aspects of project-based learning in higher education. British Journal of Educational Technology, 14(1), 66-78.

Newmann, F. M., \& Archbald, D. A. (1992). The nature of authentic academic achievement. In H. Berlak, F. M., Newmann, E., Adams, D. A., Archbald, T. Burgess, J. Raven, \& T. A. Romberg (Eds.), To- 
wards a new science of educational testing and assessment (pp. 71-84). Albany, NY: State University of New York Press.

Ronen, M., Kohen-Vacs, D., \& Raz-Fogel, N. (2006). Adopt \& adapt: Structuring, sharing and reusing asynchronous collaborative pedagogy. ICLS2006 Conference, June 27 - July 1, 2006 Indiana University, Bloomington IN. 599-606.

Struyven, K., Dochy, F., \& Janssens, S. (2005). Students' perceptions about evaluation and assessment in higher education: A review. Assessment \& Evaluation in Higher Education, 30(4), 325-341.

\section{Biographies}

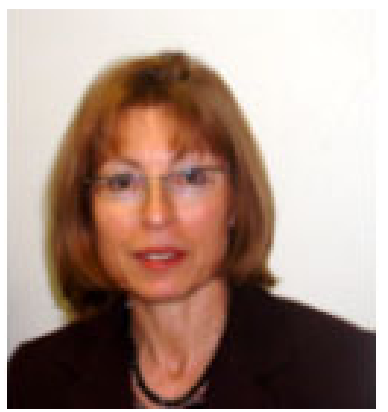

Dorothy Langley, $\mathbf{P h D}$ is a lecturer at the Department of Instructional Systems' Technologies at the Holon Institute of Technology and a member of the Physics group at the Department of Science Teaching at the Weizmann Institute of Science, Rehovot, Israel. She graduated in Physics from the Tel-Aviv University and received her $\mathrm{PhD}$ in Science Education from the Weizmann Institute of Science in 2001. Her research focuses on student learning in information technology based environments with a special interest in inquiry activities, teacher education and science teaching.

Email: langley@hit.ac.il

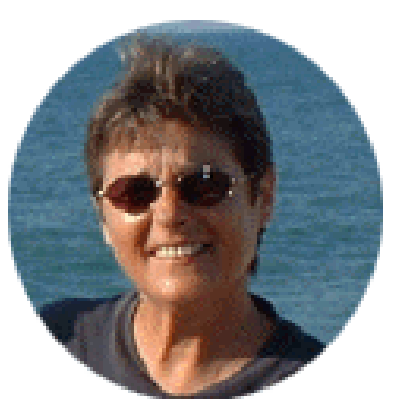

Prof. Miky Ronen is the chair of the Instructional Systems Technologies Department at the Holon Institute of Technology. Her research focuses on the instructional design of interactive learning environments and on the incorporation of technology in the teaching and learning process. She has designed and taught numerous online graduate, undergraduate and teacher training courses and faculty training programs.

Email: ronen@hit.ac.il 